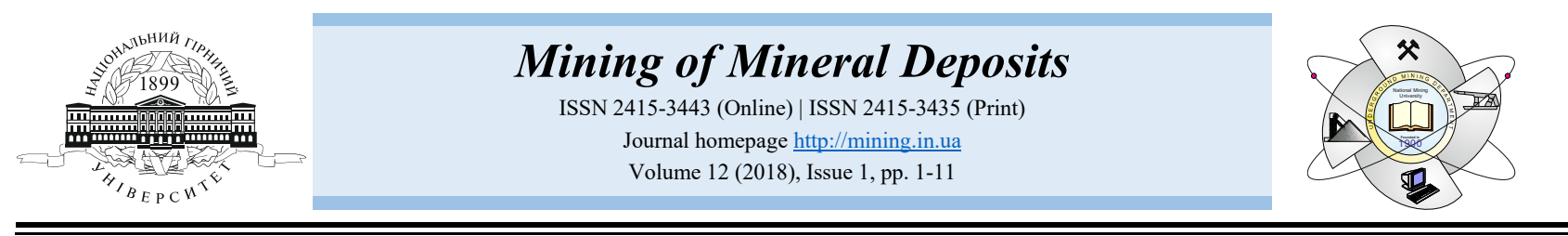

UDC 549.091

https://doi.org/10.15407/mining12.01.001

\title{
ASSESSMENT OF ENVIRONMENTAL IMPACT OF GEMSTONE MINING IN IJERO-EKITI, NIGERIA
}

\author{
T.B. Afeni ${ }^{1 *}$, F. Ibitolu ${ }^{2}$ \\ ${ }^{1}$ Federal University of Technology Akure, Akure, Nigeria \\ ${ }^{2}$ City College of New York, New York, United States \\ *Corresponding author: e-mail tbafeni@futa.edu.ng, tel. +2347065551448
}

\begin{abstract}
Purpose. To examine the environmental impacts of gemstone mining activities on the people of Ijero-Ekiti, Ekiti State, Nigeria.

Methods. Soil and water test were carried out on samples from the mine and its environment. Remote sensing as a tool for environmental assessment was introduced to generate the Normalized Difference Vegetation Index (NDVI) and Land Use Land Cover maps using ArcGIS 10 software.

Findings. Water test carried out on stream, well and pond shows that some of the samples are slightly acidic. Total Dissolved Solid and hardness analysis show ranges lower than the acceptable limit given by Nigerian Industrial Standard and the World Health Organization (WHO). Iron concentration was found to be exceptionally higher than the permissible standard given by the WHO rendering the water resources unfit for drinking. Soil test carried out in the area proved that the soil is good for agriculture as it is high in nitrogen and organic matter content.

Originality. This assertion can be back up by the results of the NDVI analysis which shows an increase in vegetation index from 0.2190 in the year of 1991 to 0.2435 in the year of 2013. Land use change detection analysis also showed a slight change in land use over the year from 2005 to 2010. This may be attributed to the fact that the gemstone mining is conducted on a small scale.

Practical implications. Test results can be used in making recommendations to the community. Farmers cultivating land where samples $S_{1}$ and $S_{4}$ were taken need to apply fertilizer to bring up the percentage of organic matter of the soil. Provision of drinkable water sources should be made to the community. Remote sensing as the applied tool has proved its usefulness in environmental degradation assessing. It gives the possibility of generating an environmental database for impact assessment in regional context which can be a difficult task when carried out by the conventional method.
\end{abstract}

Keywords: environment, gemstone mining, impact, remote sensing, vegetative index

\section{INTRODUCTION}

Exploitation of mineral resources has assumed prime importance in several developing countries including Nigeria. Nigeria is endowed with abundant mineral resources, which have contributed immensely to the national wealth with associated socio-economic benefits. Mineral resources are an important source of wealth for a nation but before they are harnessed, they have to pass through the stages of exploration, exploitation and processing (Ajakaye, 1985). Human activities are numerous and each contributes in one way or the other to the pollution of the environment. It has been observed that no single activity has caused more pollution to the environment than mineral exploitation (Afeni \& Isiaka, 2009).
This is so because exploitation of minerals involves separation of valuable minerals from the surrounding waste rocks, which in turn requires permanent disposal of unwanted or unused materials. Extraction of minerals from mines is often accompanied by severe environmental destruction by way of deforestation, earth-cutting, overburden, soil erosion, disruption of underground mine water circulation, air and water pollution and hazardous waste generation-tailings. The cost of environmental destruction is even greater when a forest cover is removed for the mining of resources. The loss of biological diversity and the extinction of elusive plant and animal species which have existed for millions of years can occur. This loss may be permanent and irreparable (Sinha, Pandey, \& Sinha, 2000). 
Generating an environmental database for carrying out environmental impact assessment in regional context and to understand deforestation in spatial and temporal domain is a difficult task by conventional methods. Today, Remote Sensing data, which is synoptic, repetitive and multi temporal in nature has efficiently filled this gap. In relation with Geographical Information System (GIS), the technique has a distinct advantage over conventional methods/approaches to map and monitor the evolution of degraded areas. It has become a versatile tool for assessing and monitoring environmental impacts as a result of natural and manmade activities (Schowengerdt, 2007). The technique has proved its usefulness in assessing the environmental degradation with reference to land, water, air and vegetation. It provides an excellent overview of the status of industrial areas and their impact. Earlier works have demonstrated its potential in various facets of industrial activity viz., land use change detection, environmental impact (Joshi, Kumar, Midha, \& Yanand, 2006). The main advantages of remote sensing are its ability to cover large areas, high temporal frequency, and lower cost compared to ground based investigation and monitoring. Remote Sensing (RS) has been widely applied in identifying and analyzing for exploitation assessment, environmental impact assessment, geomorphological analysis, land use mapping and planning (Harris \& Ventura, 1995). Usually, remotely sensed data is used to provide information on terrain surface whereas on the other hand, GIS is a supporting tool to RS and has the capability to manipulate and store data in digital forms (Shaban, 2010).

Gemstone mining has significant positive and negative impacts at a local level. On the positive side, the industry may create employment and business opportunities for local people, particularly in remote locations in developing countries where there are few other opportunities for economic development. Negative impacts include disturbance to the landscape, dust and noise, and disruption to local biodiversity from mining the gemstone.

\section{DESCRIPTION OF THE STUDY AREA}

Ijero-Ekiti under Ijero Local Government Area is located about $120 \mathrm{~km} \mathrm{NW}$ of Ado-Ekiti the capital of Ekiti State. The study area falls within the Precambian basement complex of southern Nigeria, and lies between longitudes $5^{\circ} 3^{\prime} 15.57^{\prime}$ ' $\mathrm{E}$ to $5^{\circ} 4^{\prime} 52.56^{\prime}$ ' $\mathrm{E}$ of the Greenwich Meridian and latitude $7^{\circ} 49^{\prime} 11.74^{\prime} ' \mathrm{~N}$ to $7^{\circ} 50^{\prime} 9.53^{\prime}$ ' $\mathrm{N}$ of the equator with a land mass area of $5.3 \mathrm{~km}^{2}$. It is characterized by the abundance of pegmatite which harbours minerals such as gemstones and rare earth metals as well as metallic-ores such as lepidolite among other minerals (Olusiji, 2011). Other towns around the study area include Aramoko, Ikoro, Aiyegunle, Ipoti, and Oke-Asa, with Aiyegunle in the Northeast, Ikoro in the Northwest and Oke- Asa in the Southwest. Gemstone mining in the study area started in the year 1992. Figure 1 shows the Google imagery of Ijero indicating the location where gemstone is being mined. Figure 2 show the map of Ekiti State in Nigeria showing the Ijero local government area.

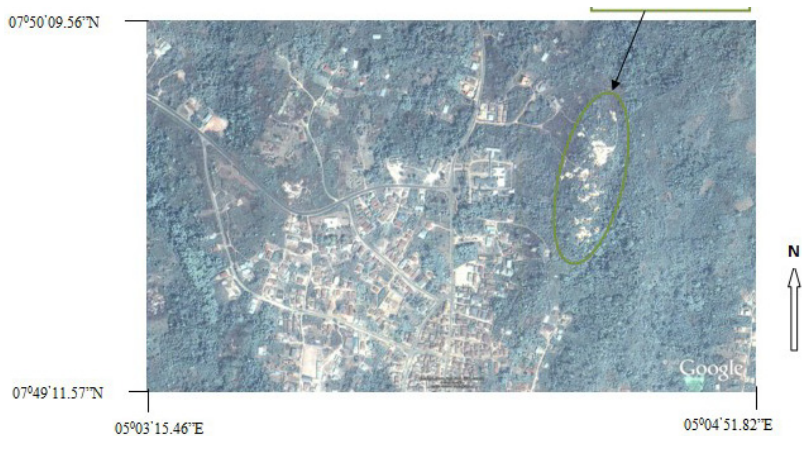

Figure 1. Google Imagery of Ijero-Ekiti

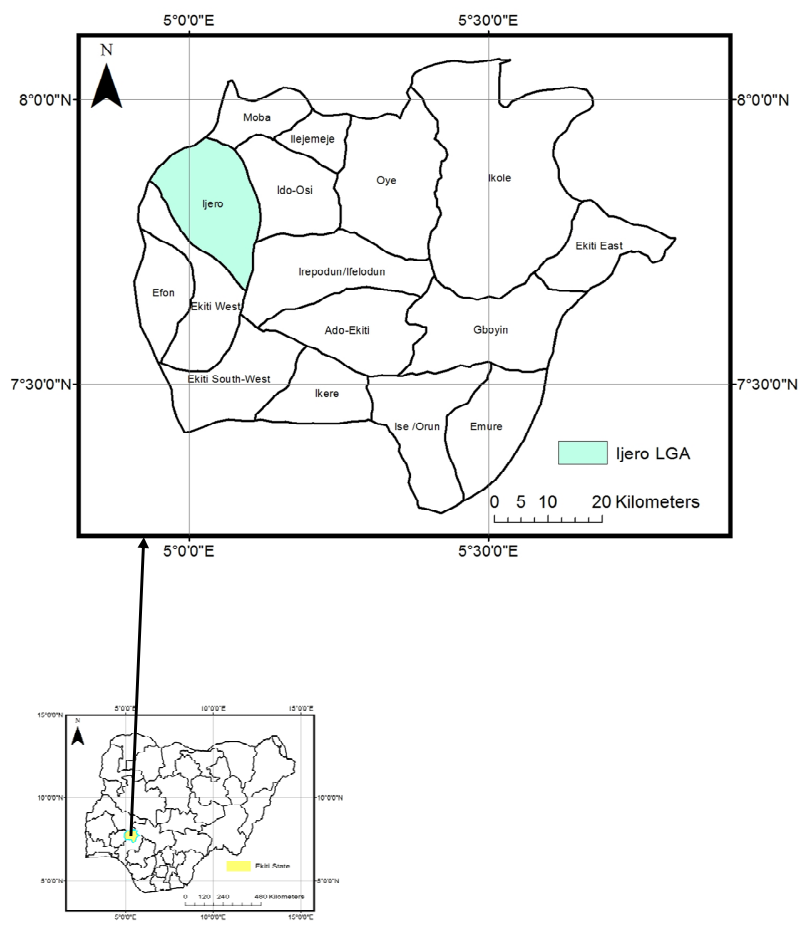

Figure 2. Map of Ekiti State in Nigeria showing the Ijero Local Government Area

\section{MATERIALS AND METHODS}

\subsection{Materials}

The material and data used for this study was acquired from two sources:

- sample collection of water and soil to see how they have been affected;

- gathering of maps, Landsat satellite imagery and Google imagery for analysis of change detection.

\subsubsection{Sample collection}

Soil samples were obtained randomly from five different locations at the study area, four samples from the disturbed/excavated area and one from an undisturbed area which is about two kilometers from the gemstone mine to serve as the control position. Each sample weighing between $1-2 \mathrm{~kg}$ was scooped within soil depth of $0-50 \mathrm{~cm}$. The samples were each put in different polythene bags, labeled $S_{1}$ to $S_{4}$ for the excavated/disturbed area and $S_{C}$ for the control sample taken from the undisturbed position before they were immediately transferred to the laboratory to avoid contamination and any possible time independent change. Also water 
samples were collected randomly from seven locations within the study area. Samples were taken from a flowing stream, wells and ponds by dipping a 2 litres plastic bottle mouth well below the water surface for the stream and pond, but for the well, a fetcher was used. The sample bottles were labeled $W_{1}$ to $W_{6}$ for the excavated area and $W_{C}$ for the control sample taken from the undisturbed position before they were quickly transferred to the laboratory for analysis that same day to prevent changes in some characteristics of the parameter to be analyzed. Table 1 shows the list of samples and the coordinates of their geographical location.

Table 1. Samples and their geographical location

\begin{tabular}{|c|c|c|c|}
\hline \multirow{2}{*}{ Samples } & \multicolumn{2}{|c|}{ Geographical Location } & \multirow{2}{*}{ Altitude (m) } \\
\hline & ${ }^{\circ} \mathrm{N}$ & ${ }^{\circ} \mathrm{E}$ & \\
\hline$S_{1}$ & $07^{\circ} 49^{\prime} 28.9^{\prime \prime}$ & $05^{\circ} 04^{\prime} 10.5^{\prime \prime}$ & 605 \\
\hline$S_{2}$ & $07^{\circ} 49^{\prime} 25.7^{\prime \prime}$ & $05^{\circ} 04^{\prime} 13.5^{\prime \prime}$ & 591 \\
\hline$S_{3}$ & $07^{\circ} 49^{\prime} 38.3^{\prime \prime}$ & $05^{\circ} 04^{\prime} 6.33^{\prime \prime}$ & 572 \\
\hline$S_{4}$ & $07^{\circ} 49^{\prime} 29.3^{\prime \prime}$ & $05^{\circ} 04^{\prime} 03.3^{\prime \prime}$ & 553 \\
\hline$S_{C}$ & $07^{\circ} 49^{\prime} 59.4 \prime$ & $05^{\circ} 03^{\prime} 12.8^{\prime \prime}$ & 526 \\
\hline$W_{1}$ & $07^{\circ} 49^{\prime} 56.4^{\prime \prime}$ & $05^{\circ} 04^{\prime} 00.3^{\prime \prime}$ & 533 \\
\hline$W_{2}$ & $07^{\circ} 49^{\prime} 27.5^{\prime \prime}$ & $05^{\circ} 04^{\prime} 03.9^{\prime \prime}$ & 537 \\
\hline$W_{3}$ & $07^{\circ} 49^{\prime} 22.7^{\prime \prime}$ & $05^{\circ} 03^{\prime} 58.6^{\prime \prime}$ & 528 \\
\hline$W_{4}$ & $07^{\circ} 49^{\prime} 26.9$ ' & $05^{\circ} 04^{\prime} 11.7$ & 582 \\
\hline$W_{5}$ & $07^{\circ} 49^{\prime} 28.9^{\prime \prime}$ & $05^{\circ} 04^{\prime} 11.3^{\prime \prime}$ & 583 \\
\hline$W_{6}$ & $07^{\circ} 49^{\prime} 37.8^{\prime \prime}$ & $05^{\circ} 04^{\prime} 04.2^{\prime \prime}$ & 545 \\
\hline$W_{C}$ & $07^{\circ} 50^{\prime} 02.6^{\prime \prime}$ & $05^{\circ} 03^{\prime} 12.9 "$ & 518 \\
\hline
\end{tabular}

\subsection{Methods}

\subsubsection{Laboratory determination of soil properties}

Samples for physio-chemical parameters were air dried in the laboratory for a week. They were then grounded into fine particles in a mortar, sieved through a $2 \mathrm{~mm}$ sieve and about $200 \mathrm{~g}$ of the sieved samples were sub-sampled by quartering for analysis.

\subsubsection{1. $\mathrm{pH}$ determination}

The $\mathrm{pH}$ of the sediment samples in water was determined by the method described by (Hendershot, Laldnde, $\&$ Duquette, 1993). From the sub-sample, $10 \mathrm{~g}$ sample were weighed into a $100 \mathrm{ml}$ beaker and $20 \mathrm{ml}$ of distilled water added. The mixture was properly stirred and allowed to stand for 30 minutes. The $\mathrm{pH}$ meter was first of all calibrated with buffer solutions of $\mathrm{pH} 4$ and 9, and this was followed by dipping the electrode into the sample solution and the $\mathrm{pH}$ read on a JENWAY $\mathrm{pH}$ meter. On each occasion, the electrode was rinsed with distilled water before insertion into another sample.

\subsubsection{Organic carbon and matter determination}

The organic carbon was determined using wet oxidation method of Walkley and Black described by (Schulte, 1995). About $5 \mathrm{~g}$ of sieved samples were weighed and transferred into $250 \mathrm{ml}$ conical flask. $10 \mathrm{ml}$ of $0.5 \mathrm{M}$ $\mathrm{K}_{2} \mathrm{Cr}_{2} \mathrm{O}_{7}$ (potassium dichromate) were added followed by $20 \mathrm{ml}$ of conc. $\mathrm{H}_{2} \mathrm{SO}_{4}$. The flask was immediately swirled to mix the content. The mixture was then swirled more rigorously for one minute and allowed to stand on a sheet of asbestos for about 30 minutes. $200 \mathrm{ml}$ of distilled water and $10 \mathrm{ml}$ conc. $\mathrm{H}_{3} \mathrm{PO}_{4}$ were added to the sample and allowed to cool to room temperature. 3 drops of ferroin indicator were then added and titrated with $0.5 \mathrm{M}$
$\left(\mathrm{NH}_{4}\right) \mathrm{Fe}\left(\mathrm{SO}_{4}\right)_{2} \cdot 6 \mathrm{H}_{2} \mathrm{O}$ (ferrous ammonium sulphate) solution to brownish red end point. Blank titration was conducted in the same manner, but without the sediment samples. The percentage total organic carbon and the organic matter were calculated for each sample thus:

$\%$ Organic carbon $=\frac{(B-S) \cdot M \cdot 100}{\text { weight of sample }(g)} \cdot \frac{12}{4000}$,

where:

$B-\mathrm{ml}$ of ferrous ammonium sulphate used for blank;

$S-\mathrm{ml}$ of ferrous ammonium sulphate used for sample;

$M$ - Molarity of ferrous ammonium sulphate;

$12 / 4000-$ milliequivalent of carbon in $\mathrm{g}$.

$\%$ Organic matter $=\%$ Organic carbon $\cdot \frac{1.72}{0.58}$.

\subsubsection{Determination of percentage nitrogen in soil}

The organic nitrogen content was determined by the Kjedahl procedure. About 1g of the sample was digested with $15 \mathrm{ml}$ conc. $\mathrm{H}_{2} \mathrm{SO}_{4}$ and 1 tablet of copper analyst until a clear solution was obtained. The solution was made up to $50 \mathrm{ml}$ with distilled water. $15 \mathrm{ml}$ of the solution was measured into the distillation flask followed by $25 \mathrm{ml}$ of the $40 \%$ sodium hydroxide solution. $5 \mathrm{ml}$ of $2 \%$ boric acid solution was measured into a conical flask followed by 2 drops of mixed indicator $(0.01 \mathrm{~g}$ of methyl red and $0.083 \mathrm{~g}$ of bromocresol green were dissolved in $100 \mathrm{ml}$ of alcohol) (a light brown or fade orange colour was obtained). The distillation was carried out with all joint tightened with the end of the delivery tube dipped below the boric acid solution. As the distillation proceeds, the light brown colour changes to blue indicating the presence of ammonia. Distillation continued until the distillate was up to $50 \mathrm{ml}$. The distillate was titrated with $0.1 \mathrm{M} \mathrm{HCl}$ until the blue colour became colourless. The titre value was obtained and the percentage nitrogen was obtained through which the crude protein was evaluated.

Digestion:

$\mathrm{RNH}_{2}+2 \mathrm{H}_{2} \mathrm{SO}_{4} \rightarrow\left(\mathrm{NH}_{4}\right)_{2} \mathrm{SO}_{4}+\mathrm{CO}_{2}+\mathrm{H}_{2} \mathrm{O}$.

Distillation:

$\left(\mathrm{NH}_{4}\right)_{2} \mathrm{SO}_{4}+2 \mathrm{NaOH} \rightarrow \mathrm{NH}_{3}+\mathrm{H}_{2} \mathrm{O}+\mathrm{Na}_{2} \mathrm{SO}_{4}$.

Absorption:

$3 \mathrm{NH}_{3}+\mathrm{H}_{3} \mathrm{BO}_{3} \rightarrow\left(\mathrm{NH}_{4}\right)_{3} \mathrm{BO}_{3}$.

Titration:

$$
\begin{aligned}
& \left(\mathrm{NH}_{4}\right)_{3} \mathrm{BO}_{3}+\mathrm{HCl} \rightarrow \mathrm{H}_{3} \mathrm{BO}_{3}+3 \mathrm{NH}_{4} \mathrm{Cl} \text {. } \\
& \% \mathrm{~N}=\frac{\text { molarity of acid } \cdot 0.0014 \cdot \text { volume of acid }}{\text { weight of sample }} .
\end{aligned}
$$

\subsubsection{Water sample analysis}

Samples were analysed for other physio-chemical parameters and chemical pollutants using methods prescribed by Wershaw, Fishman, Grabbe, \& Lowe (1987), Fishman \& Friedman (1989) and Ademoroti (1996).

\subsubsection{Determination of $\mathbf{p H}$}

This was determined as described by Ademoroti (1996). The Jenway $3505 \mathrm{pH}$ meter was first standard- 
ized using standard buffer solutions of $\mathrm{pH} 4$ and $\mathrm{pH} 9$. From the sample, $100 \mathrm{ml}$ of water were weighed into a $100 \mathrm{ml}$ beaker. The electrode was carefully suspended in the sample and allowed to stand until the reading was steady before the reading was finally recorded. After each measurement, the electrode will be cleaned with distilled water.

\subsubsection{Determination of electrical conductivity}

This was determined as described by Ademoroti (1996). The conductometer used is conductivity measuring Labtech instrument. The samples were thoroughly mixed together before an aliquot was poured into the meter sample holder. Immediately the reading knob was depressed, the reading was taken and recorded for each sample.

\subsubsection{Determination of water temperature}

This will be determined using a thermometer which will read the temperature of the environment and then dipped into the water sample.

\subsubsection{Determination of turbidity}

Turbidity was determined by the Nephelometric method using a portable LABTECH turbidity meter. The instrument was first calibrated with standard turbidity suspension supplied with the instrument after setting to read turbidity. The sample was then thoroughly shaken so as to disperse the solid contents and some quantity was poured into the turbidimeter tube and the turbidity read from the instrument. Distilled water was used to zero the instrument in every measurement.

\subsubsection{Determination of water alkalinity}

Alkalinity was determined titrimetrically in the water samples using the indicator method. Carbonate and hydroxide were determined by titrating $50 \mathrm{ml}$ of the sample with standard $0.01 \mathrm{M} \mathrm{H}_{2} \mathrm{SO}_{4}$ after the addition of 3 drops of phenolphthalein indicator. This gave the phenolphthalein alkalinity. If there was no colour when the indicator was added, then carbonate and hydroxide were absent.

Bicarbonate or methyl orange indicator alkalinity followed immediately after the phenolphthalein alkalinity determination by the addition of 3 drops of methyl orange into the sample and continued the titration with the standard $\mathrm{H}_{2} \mathrm{SO}_{4}$ from yellow to orange-red colour end point. Then phenolphthalein, methyl orange and total alkalinities were calculated thus.

Phenolphthalein alkalinity:

$$
\mathrm{mg} / 1 \mathrm{CaCO}_{2}=\frac{V_{p} \cdot M \cdot 100000}{\text { volume of sample }},
$$

where:

$V_{p}$-volume of acid used with phenolphthalein as indicator;

$M$ - molarity of the acid.

Methyl orange (bicarbonate) alkalinity:

$\mathrm{mg} / 1 \mathrm{HCO}_{2}=\frac{V_{m} \cdot M \cdot 61000}{\text { volume of sample }}$

where:

$V_{m}$ - volume of acid used with methyl orange as indicator.
Total Alkalinity:

$\mathrm{mg} / 1 \mathrm{CaCO}_{3}=\frac{\left(V_{p}+V_{m}\right) \cdot M \cdot 100000}{\text { volume of sample }}$.

\subsubsection{Determination of water hardness}

Total hardness in the water samples was determined titrimetrically using the sodium salt of ethylene-diaminetetra-acetic acid (EDTA) as titrant.

Into $50 \mathrm{ml}$ of the water sample were added $2 \mathrm{ml} \mathrm{am}$ monia/ammonium chloride buffer $(\mathrm{pH}=10)$ and $2 \mathrm{ml}$ of sodium cynide $(\mathrm{NaCN})$ as masking agent. This was followed by the addition of little quantity of Erichrome Black $\mathrm{T}$ indicator mixture (Erichrome Black $\mathrm{T}+\mathrm{NaCl}$ ) and the solution titrated with $0.01 M$ EDTA solution to the end point. The total hardness in $\mathrm{mg} / \mathrm{CaCO}_{3}$ was calculated from the titre value thus:

$$
\mathrm{mg} / 1 \mathrm{CaCO}_{3}=\frac{m l \text { of } 0.01 \mathrm{M} \text { EDTA } \cdot 1000}{\text { volume of sample }} .
$$

\subsubsection{Determination of ammonia}

All forms of nitrogen that can exist as ammonium ion or in the equilibrium as:

$\mathrm{NH}_{4}^{+} \Leftrightarrow \mathrm{NH}_{3}+\mathrm{H}^{+}$,

is considered as ammonia nitrogen. It was determined by direct nesslerisation method (Ademoroti, 1996).

Into $50 \mathrm{ml}$ of the water sample was added 1 drop of EDTA reagent to remove the precipitate of cations e.g. $\mathrm{Ca}^{2+}, \mathrm{Mg}^{2+}$ etc. that can produce precipitate or turbidity with Nessler ragent. This was followed by the addition of $2 \mathrm{ml}$ Nessler reagent for the colour to develop. The coloured solution was shaken together and part put into a lovibond tube and inserted into the lovibond comparator casing. Distilled water used as blank was put in another tube and inserted into the other compartment of the casing. The ammonia standard glass disc was rotated until there was a colour match with that of the solution. The reading was taken directly from the graduated disc.

\subsubsection{Sulphate determination}

Sulphate in the water samples was determined by turbidimetric method (Ademoroti, 1996).

$100 \mathrm{ml}$ of sample were measured into a $250 \mathrm{ml}$ conical flask and $5 \mathrm{ml}$ of phosphate conditioning reagent were added. While stirring on a magnetic stirrer, a spoonful of barium chloride crystals was added and stirred for another one minute at constant speed. Part of the solution was then poured into an absorption cell and the absorbance read at $425 \mathrm{~nm}$. Standard solutions of sulphate $(2-10 \mathrm{mg} / \mathrm{l})$ were prepared and treated the same way as the sample. Sulphate concentrations were determined by extrapolation from the calibration curve prepared from the standards.

\subsubsection{Metals determination in water}

The water samples were first digested with conc. $\mathrm{HNO}_{3}$ and pre-concentrated before analysis using Atomic Absorption Spectrophotometer (AAS). $100 \mathrm{ml}$ of well mixed water sample was measured into a $250 \mathrm{ml}$ beaker and $10 \mathrm{ml}$ conc. $\mathrm{HNO}_{3}$ was added. The solution was evaporated to near dryness on hot plate under a medium heat 
(solution not allowed to boil). The beaker with the content was allowed to cool to room temperature after which another $10 \mathrm{ml}$ portion of conc. $\mathrm{HNO}_{3}$ and $5 \mathrm{ml} \mathrm{H}_{2} \mathrm{O}_{2}$ were added. The beaker was immediately covered with a watch glass and returned to the hot plate and heated under a gentle reflux action. This was continued until a whitish residue was obtained. The residue was then filtered after cooling through Whatman filter paper into a $25 \mathrm{ml}$ volumetric flask and made to the mark with distilled water. The solution was then transferred into a polythene bottle prior AAS analysis. For every batch of samples, reagent blanks were prepared in similar manner as in the sample preparation using distilled water in place of sample. All solutions were analysed for heavy metals using AAS Buck Scientific 210 VGP model. Analysis of a mixture of metal standards $(\mathrm{Cr}, \mathrm{Fe}$ and $\mathrm{Zn}$ ) prepared from their stock solutions was also carried out as part of the analytical data quality assurance. Evaluation of accuracy and precision of the analytical instrument was performed by replicate analyses of the mixture of standards, with results showing good agreement between instrument and the standard values.

\subsubsection{Determination of total dissolved solid (TDS)}

The sample was first filtered using a Whatman filter paper. $50 \mathrm{ml}$ of the filtrate was then transferred into a previously weighed evaporating dish. This was evaporated to dryness on an electric hot plate before drying to a constant weight in the oven at $150^{\circ} \mathrm{C}$. The weight of the dish was subtracted from the final weight to obtain the weight $(\mathrm{mg})$ of the TDS:

TDS $\mathrm{mg} / 1=\operatorname{mg}$ TDS $\cdot 1000 / \mathrm{ml}$ of filtrate taken .

\subsubsection{Satellite image processing}

\subsubsection{Normalized Difference Vegetation Index (NDVI)}

Normalized Difference Vegetation Index (NDVI) is a calculation based on several spectral bands of the photosynthetic output (amount of green) in a pixel in a satellite image. It measures, in effect the amount of green vegetation in an area (Nouri, Beecham, Anderson, \& Nagler, 2014). NDVI gives a measure of the vegetative cover on the land surface over wide areas. Vegetation differs from other land surfaces because it tends to absorb strongly the red wavelengths of sunlight and reflect in the nearinfrared wavelengths. NDVI, as an indicator of the health/state of vegetation ranges from -1 to +1 whereby rich and healthy vegetation is represented as +1 while a poor vegetated land is represented close to -1 . Water body is also represented as -1 . NDVI is calculated from the Red (R) and Near-Infrared (NIR) bands of the Electromagnetic Spectrum (EM) whereby in case of Landsat 7 ETM+ used in this study, the red band is band 3 while the near-infrared channel is band 4 . The equation is given as:

$$
\mathrm{NDVI}=\frac{(\mathrm{NIR}-\mathrm{R})}{\mathrm{NIR}+\mathrm{R}}=\frac{\text { band } 4-\text { band } 3}{\text { band } 4+\text { band } 3} \text {. }
$$

Landsat Satellite imagery data for four different years period of 1991, 2000, 2010 and 2013 were used for the NDVI analysis. The data used are Landsat 4 TM for 1991, Landsat 7 ETM+ for 2000, Landsat 7 ETM+ for 2010 and Landsat 7 ETM+ for 2013. A summary of all satellite data used in this research is shown on Table 2 below.
Table 2. Satellite dataset used

\begin{tabular}{lcccc}
\hline \multicolumn{1}{c}{ Satellite } & Sensor & $\begin{array}{c}\text { Year of } \\
\text { acquisition }\end{array}$ & Source & $\begin{array}{c}\text { Spatial } \\
\text { resolution }\end{array}$ \\
\hline Landsat 4 & TM & 1991 & USGS & $30 \mathrm{~m}$ \\
Landsat 7 & ETM+ & 2000 & USGS & $30 \mathrm{~m}$ \\
SPOT & - & 2005 & - & $5 \mathrm{~m}$ \\
Landsat 7 & ETM+ & 2010 & USGS & $30 \mathrm{~m}$ \\
Digital Globe & - & 2010 & - & $0.32 \mathrm{~m}$ \\
Landsat 7 & ETM+ & 2013 & USGS & $30 \mathrm{~m}$ \\
\hline
\end{tabular}

As a result of the failure of the side looking camera (SLC) of Landsat satellite that occurred in year 2003; all imageries acquired after this year has some strip on them. The Focal Analysis Tool of ERDAS Imagine 9.2 software was used to remove the strips on the imageries before using them on ArcGIS 10. Using the NDVI thresholds Calculator in ArcGIS 10 and inputting the red and near-infrared band, the multi-temporal NDVI maps were created as illustrated on the print screen image in Figure 3.

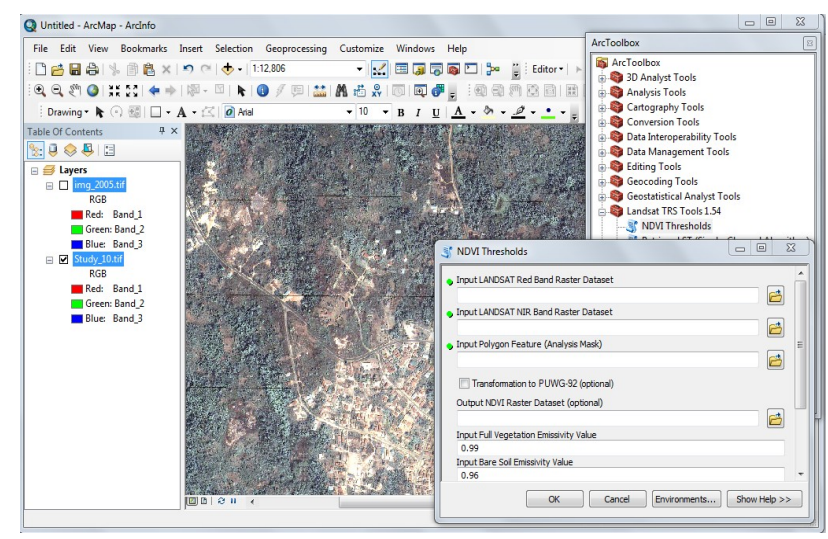

Figure 3. Screen capture of the NDVI threshold page in ArcGIS software (Source - Acquired from the Research Work, 2015)

\subsubsection{Land use change detection}

Studying changes in land use pattern using remotely sensed data is based on the comparison of the time sequential data. Difference in surface phenomenon over time can be determined and evaluated (Garg, Narayan, \& Basu, 1988; Space Application Centre, 1990; Gregorio \& Jansen, 1998). To create a Land Use Land Cover (LULC) map, an image of high resolution is required in other to have an accurate analysis. However, SPOT imagery was obtained for year 2005 while Digital globe imagery was used for year 2010.

The LULC map was created using ArcGIS 10 software based on four classes as listed below:

- forest;

- open ground/Area under mining operation;

- settlement/built-up area;

- grassland/non forest;

Spectral signature for the various features was created and then Maximum Likelihood Classification method was used for this purpose. 


\section{RESULTS AND DISCUSSION}

\subsection{Water and soil analysis}

\subsubsection{Water analysis}

The result obtained from the water analysis is presented in Table 3 as compared with some limits like World Health
Organization (WHO) (Guidelines..., 2011) and Nigerian Industrial Standard (NIS, 2007) as baseline for comparison.

The result of the $\mathrm{pH}$ obtained from the analysis of water samples from a stream at the base of the hill, ponds and wells located in residential houses show the $\mathrm{pH}$ ranges between 6.15 and 7.33 .

Table 3. Result of water analysis

\begin{tabular}{|c|c|c|c|c|c|c|c|c|c|c|c|c|c|c|}
\hline $\mathrm{S} / \mathrm{N}$ & $\begin{array}{l}\text { Distance } \\
\text { from } \\
\text { mine }(\mathrm{m}) \\
\end{array}$ & $\begin{array}{c}\text { Sample } \\
\text { Origin }\end{array}$ & $\begin{array}{c}\text { Temp } \\
\left({ }^{\circ} \mathrm{C}\right)\end{array}$ & $\mathrm{pH}$ & $\begin{array}{c}\text { TDS } \\
(\mathrm{mg} / \mathrm{l})\end{array}$ & $\begin{array}{l}\text { Alkalinity } \\
\text { (mg/l) }\end{array}$ & $\begin{array}{c}\text { Hard- } \\
\text { ness } \\
(\mathrm{mg} / \mathrm{l}) \\
\end{array}$ & $\begin{array}{l}\text { Conduc- } \\
\text { tivity } \\
(\mu \mathrm{s} / \mathrm{cm})\end{array}$ & $\begin{array}{c}\text { Turbidity } \\
\text { (NTU) }\end{array}$ & $\begin{array}{l}\mathrm{SO}_{4}{ }^{2-} \\
(\mathrm{mg} / \mathrm{l})\end{array}$ & $\begin{array}{c}\mathrm{NH}_{3} \\
\text { (Hazen) }\end{array}$ & $\begin{array}{c}\mathrm{Fe} \\
(\mathrm{ppm})\end{array}$ & $\begin{array}{c}\mathrm{Zn} \\
(\mathrm{ppm})\end{array}$ & $\begin{array}{c}\mathrm{Cr} \\
(\mathrm{ppm})\end{array}$ \\
\hline$W_{1}$ & 773 & Stream & 29.50 & 7.13 & 70 & 160 & 96.60 & 120 & 9.70 & 6.30 & 3 & 12.50 & 0.10 & ND \\
\hline$W_{2}$ & 366 & Well & 29.00 & 6.32 & 100 & 72 & 54.60 & 190 & 3.50 & 2.30 & 2 & 1.22 & 0.04 & ND \\
\hline$W_{3}$ & 580 & Well & 30.50 & 6.50 & 150 & 224 & 113.40 & 330 & 0.50 & 2.32 & 2 & 0.39 & 0.02 & ND \\
\hline$W_{4}$ & 243 & Pond & 29.50 & 7.33 & 60 & 104 & 16.80 & 120 & 5.30 & 71.93 & 2 & 1.75 & 0.06 & ND \\
\hline$W_{5}$ & 185 & Pond & 30.00 & 6.50 & 50 & 40 & 29.40 & 100 & 2.60 & 81.21 & 2 & 0.61 & 0.06 & ND \\
\hline$W_{6}$ & 341 & Well & 30.00 & 6.15 & 90 & 56 & 63.00 & 210 & 1.10 & 18.56 & 2 & 0.66 & 0.06 & ND \\
\hline$W_{C}$ & 2030 & Pond & 30.00 & 6.70 & 140 & 272 & 109.20 & 190 & 0.40 & 37.12 & 5 & 3.84 & 0.04 & ND \\
\hline WHO & & & NA & $6.5-8.5$ & 1000 & 100 & 500.00 & NA & 5.00 & 400.00 & NA & 0.30 & 5.00 & 0.05 \\
\hline NIS & & & NA & $6.5-8.5$ & 500 & NA & 150.00 & 1000 & 5.00 & 100.00 & NA & 0.30 & 3.00 & 0.05 \\
\hline
\end{tabular}

This indicates that some of the samples were acidic while others were alkaline in nature. Most of the $\mathrm{pH}$ values of the water were within the WHO and NIS permissible limits $(6.5-8.5)$. Only the $\mathrm{pH}$ of $W_{2}(6.32)$ and $W_{6}(6.15)$ fell out of the WHO and NIS acceptable limit. Looking at the $\mathrm{pH}$ values of the water samples when compared with their distance from the mine as shown in Figure 4 below, it is seen that the rate of increase and decrease in $\mathrm{pH}$ is not relative to the distance from the mine.

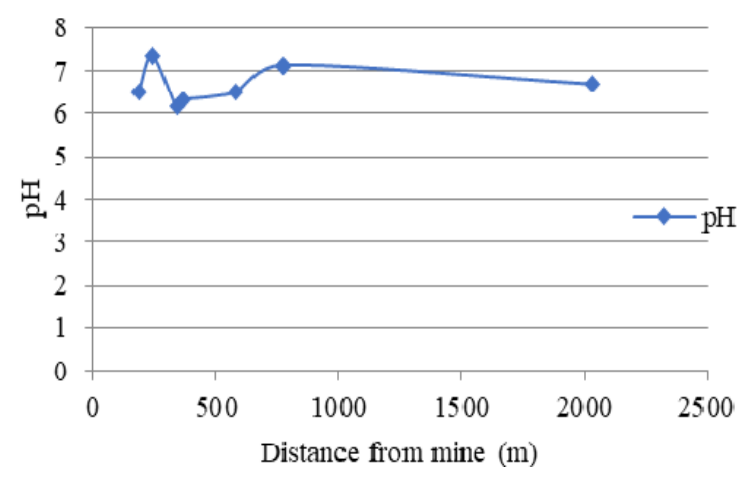

Figure 4. Graph of pH values of water sample against distance from mine

The $\mathrm{pH}$ of the control sample $W_{C}(6.70)$ shows that the water is slightly acidic and that the acidic nature of some of the other water samples from the disturbed area may not even be as a result of the mining activity in the area. With the $\mathrm{pH}$ obtained although most of the water samples still falling within the standard limit, the waters will not be suitable for human consumption, but could be used for irrigation purposes.

Total Dissolved Solid. The result of the TDS obtained from the water analysis shows that the TDS ranges between 50 and $150 \mathrm{mg} / \mathrm{l}$. TDS which is a measure of total number of ionizable materials present in the water. When compared with the WHO and NIS acceptable limits $(1000 \mathrm{mg} / \mathrm{l}$ and $500 \mathrm{mg} / \mathrm{l}$ respectively), the TDS value of all the water samples including the control sample $W_{C}$ was low.

Hardness. The hardness of the water samples including the control sample ranges between 16.8 and
$113.40 \mathrm{mg} / \mathrm{l}$. All were found to be within the permissible limit as given by WHO and NIS as $500 \mathrm{mg} / \mathrm{l}$ and $150 \mathrm{mg} / \mathrm{l}$ respectively.

Electrical Conductivity. The electrical conductivity of the water samples ranges between 100 and $330 \mu \mathrm{s} / \mathrm{cm}$ and they are within the maximum allowable limits when compared with NIS standard $(1000 \mu \mathrm{s} / \mathrm{cm})$. The slightly high conductivity of the samples reveals that more ions were dissolved in the water.

Turbidity. Turbidity in the water samples ranges between 0.4 to 9.70 NTU. Most of the samples were within the permissible limit of 5 NTU as given by both WHO and NIS. However, samples $W_{1}$ and $W_{4}$ show a turbidity of 9.7 and 5.3 respectively. This was caused by the high suspended load from the water discharged during the pumping of water out of the Mine Lake or pond.

The concentration of Sulphate ion $\left(\mathrm{SO}_{4}{ }^{2-}\right)$ required in a drinking water as given by NIS and WHO is $100-400 \mathrm{mg} / \mathrm{l}$, but its concentration is very low in the water samples taken from the study area. Iron concentration was found to be exceptionally higher than the maximum permissible limits as prescribed by WHO and NIS standards as $0.3 \mathrm{mg} / \mathrm{l}$. The result of the iron concentration in the water samples ranges between 0.39 and $12.50 \mathrm{ppm}$. Since we have high concentration of iron in the samples, hence the water is not fit for drinking. The zinc concentration of the water samples taken was found to be within the safe limit for drinking as the sample ranges between 0.02 to $0.1 \mathrm{ppm}$ while the permissible limit is 5 and $3 \mathrm{mg} / \mathrm{l}$ for WHO and NIS respectively. The result of the concentration of Chromium $\left(\mathrm{Cr}^{2+}\right)$ in the water sample was not detected (ND) as given by the AAS analysis.

\subsubsection{Soil analysis}

The result obtained from the soil analysis carried out in the laboratory is presented in Table 4.

The $\mathrm{pH}$ of the soil as shown in the table ranges between 5.66 and 6.95 for samples $S_{1}$ to $S_{4}$ while $\mathrm{pH}$ of the control sample $S_{C}$ is 6.76 . This result shows that the study area is slightly acidic in nature. Some of the samples from the excavated areas are more acidic than that of the control station. 
Table 4. Result of soil analysis*

\begin{tabular}{cccccc}
\hline Samples & $\begin{array}{c}\text { Distance } \\
\text { from } \\
\text { mine }(\mathrm{m})\end{array}$ & $\mathrm{pH}$ & $\begin{array}{c}\% \\
\text { Nitrogen }\end{array}$ & $\begin{array}{c}\% \\
\text { Organic } \\
\text { carbon }\end{array}$ & $\begin{array}{c}\% \\
\text { Organic } \\
\text { matter }\end{array}$ \\
\hline$S_{1}$ & 194 & 5.66 & 0.69 & 0.08 & 0.23 \\
$S_{2}$ & 280 & 5.84 & 0.70 & 1.49 & 4.43 \\
$S_{3}$ & 304 & 6.05 & 0.71 & 0.95 & 2.83 \\
$S_{4}$ & 346 & 6.95 & 0.70 & 0.45 & 1.34 \\
$S_{C}$ & 2029 & 6.76 & 0.73 & 1.68 & 5.67 \\
\hline
\end{tabular}

"Source - author's field sample survey, 2014

This could be as a result of the excavation activities going on the disturbed area. Also when the $\mathrm{pH}$ value of the samples are plotted against sample distance from the gemstone mine as shown on Figure 5, it is observed that the $\mathrm{pH}$ of the soil samples increases as distance away from mining activity increases.

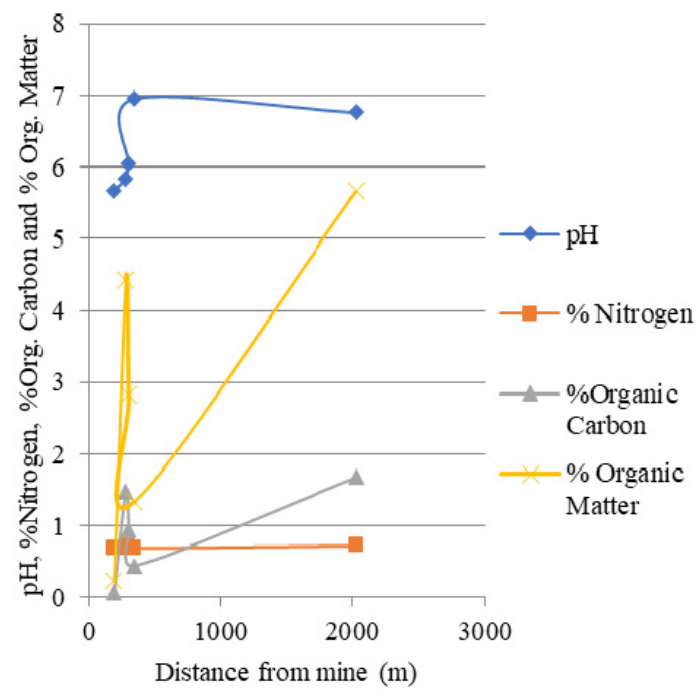

Figure 5. Graph of pH, \% Nitrogen, \% Organic Carbon and $\%$ Organic Matter against the sample distance from the mine

The Organic Carbon and Nitrogen levels in the soil samples were interpreted using the guidelines in Table 5, regarding the carbon and nitrogen levels in agricultural soil (Tekalign, Haque, \& Aduayi, 1991).

Table 5. Guidelines on interpretation of soil carbon and nitrogen test results

\begin{tabular}{ccc}
\hline Soil Parameter & Measured Value & Rating \\
\hline & $>3.0$ & High \\
Organic Carbon, \% & $1.5-3.0$ & Moderate \\
& $0.5-1.5$ & Low \\
& $<0.5$ & Very Low \\
\hline & $>0.25$ & High \\
Total Nitrogen, \% & $0.12-0.25$ & Moderate \\
& $0.05-0.12$ & Low \\
& $<0.05$ & Very Low \\
\hline
\end{tabular}

The Nitrogen level in all the soil samples from both the excavated and non-excavated area is rated high. Since nitrogen is a key nutrient for plant growth, the high percentage of nitrogen present in the soil gives opportunity for growth of green plants, crops and bushes as seen around the study area. The percentage of the soil organic carbon from the analysis table ranges between 0.08 and
1.49 except for that of the control position is 1.68 . This shows that the organic carbon rating for sample $S_{1}$ is very low while $S_{3}$ and $S_{4}$ are rated low. However, samples $S_{2}$ and $S_{C}$ are rated moderate in organic carbon. Although the organic carbon is not a requirement for plant growth, it only influences a number of soil chemical and physical processes. From Figure 5, it is seen that the \% Nitrogen and $\%$ Organic Carbon did not necessarily increase with distance from the mine.

The percentage soil organic matter ranges between 0.23 and 5.67 for both the excavated and undisturbed area. The soil organic matter improves the soil moisture, soil structure and conditions for microbial growth and hence and important factor for the soil as a rooting environment. Typical topsoil commonly contain about $2-5 \%$ by weight of organic matter. Samples $S_{2}$ and $S_{3}$ were within the range except for $S_{1}(0.23 \%)$ and $S_{4}$ $(1.34 \%)$ that were found to be low and the control sample $S_{C}$ having higher organic matter attributed to being at a farther distance from the disturbed/excavated area.

\subsubsection{Satellite image processing}

\subsubsection{Normalized Difference Vegetation Index (NDVI)}

The Normalized Difference Vegetation Index (NDVI) is commonly used as a measure of land surface greenness based on the assumption that NDVI value is positively proportional to the amount of green vegetation in an image pixel area. Figures $6 \mathrm{a}-\mathrm{d}$ show the variation of spatial pattern of NDVI for the study area in 1991, 2000, 2010 and 2013 respectively.

From Table 6 and Figure 7 which shows a summary of the NDVI values for each period of study, the mean NDVI value tend to decrease over time from 1991 (0.210) to 2010 (0.115). Between 2010 and 2013, there is a sharp increase in the mean NDVI with year 2013 have a value of 0.2435 .

Table 6. Summary of NDVI during the period of study $(a-d)$

\begin{tabular}{ccccc}
\hline Range/Year & 1991 & 2000 & 2010 & 2013 \\
\hline Min & 0.010 & -0.2164 & -0.0490 & -0.0550 \\
Mean & 0.219 & 0.1338 & 0.1150 & 0.2435 \\
Max & 0.4290 & 0.4840 & 0.2790 & 0.5420 \\
\hline
\end{tabular}

Looking at the minimum NDVI value gotten for the period of study, it is seen that it is only in 1991 that a negative value is not recorded. This can be attributed to the fact that the area is untampered with (coupled with less urbanization) as regards to mining activity. Over the years as mining activity continues, it is seen that vegetation reduces as we have a decrease in the value of the mean NDVI from 0.219 in the year 1991 to 0.115 in 2010 . But a sharp increase is recorded in 2013 as the value of the mean NDVI increases from 0.115 in 2010 to 0.2435 in 2013. This can be attributed to improvement in farm practices and possibly application of new farming method and fertilizers.

\subsubsection{Land use change detection}

In order to put any change into a proper perspective, it is useful to establish the state of the environment in the selected years. The extent of each land use/land cover (LULC) in 2005 and 2010 were analysed in order to get an overview of changes in magnitude so as to justify the change analysis (Figure 8, 9). 
(a)

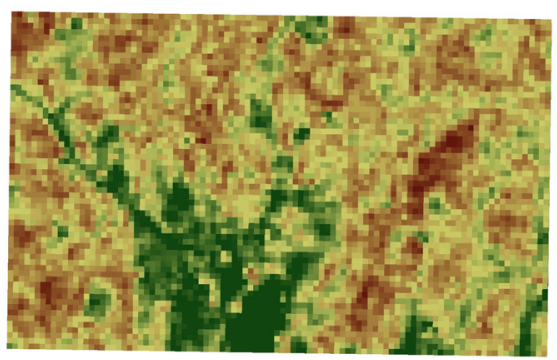

(c)

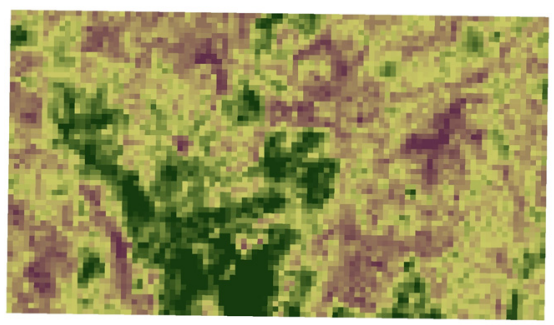

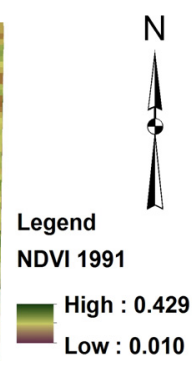

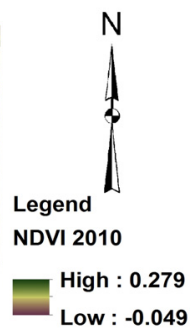

(b)

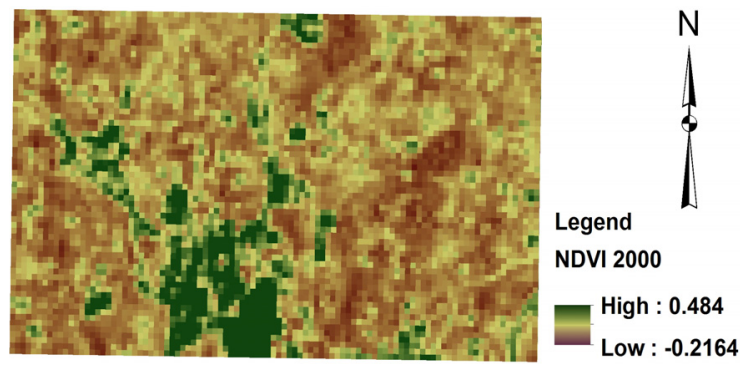

(d)

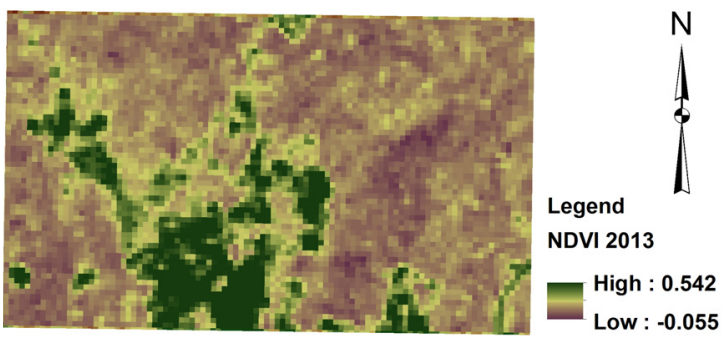

Figure 6. Spatial pattern of NDVI for the study area in the year: (a) 1991; (b) 2000; (c) 2010 and (d) 2013

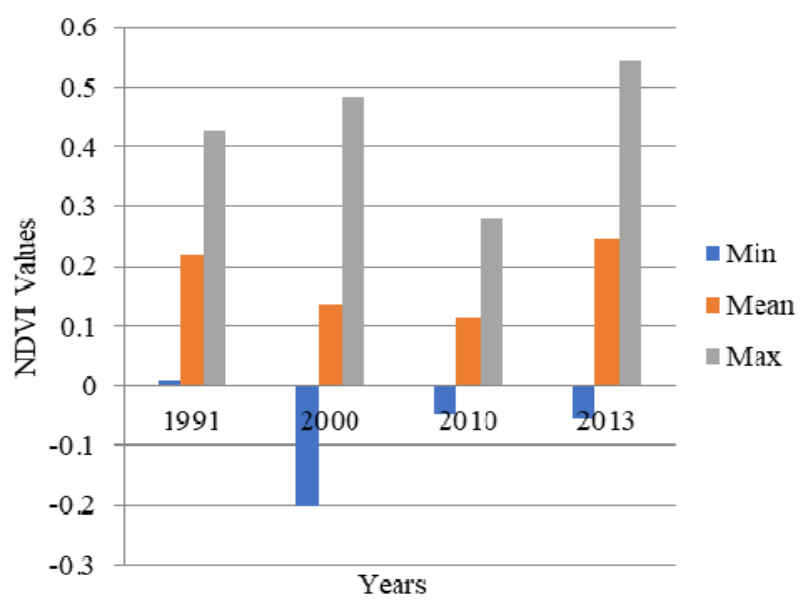

Figure 7. Bar chart distribution of NDVI during 1991, 2000, 2010 and 2013

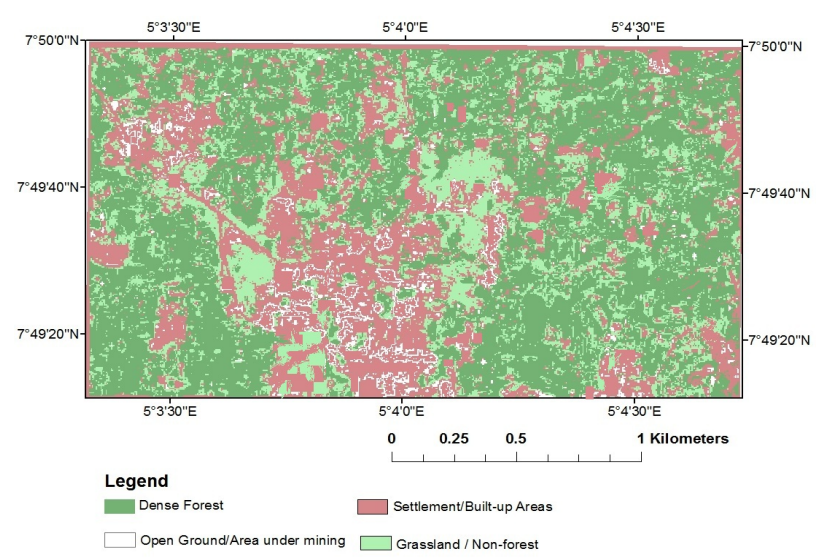

Figure 8. Land use land cover map of the study area for 2005

It should be noted that the two years selected $(2005$ and 2010) for LULC were chosen based on the availability of high resolution imagery for the study area.

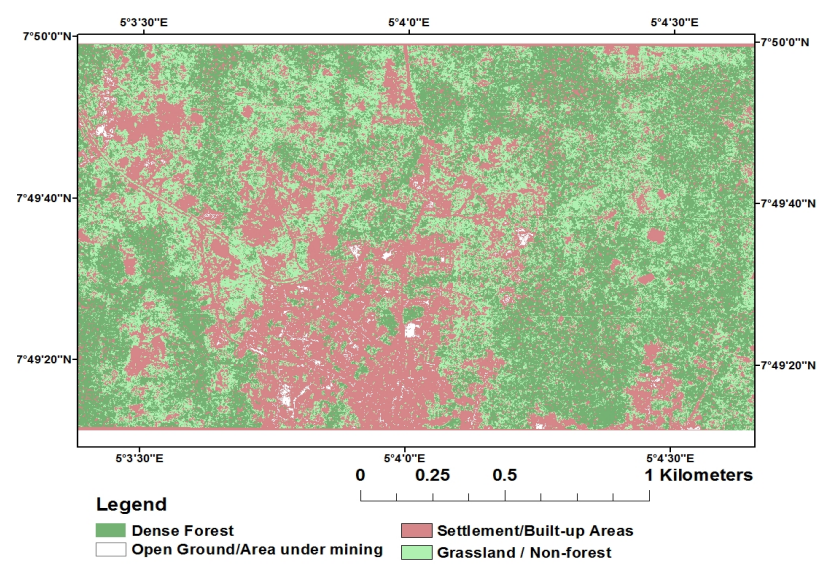

Figure 9. Land use land cover map of the study area for 2010

From the analysis carried out on the acquired images using the ArcGIS software, it was discovered as shown in Table 7 that most of the areas were less developed and hence dominated by dense forest and grassland $(69.34 \%$ to $68.49 \%$ ) during the period of study. However, there was a slight decrease in the dense forest from $40.04 \%$ in year 2005 to $40 \%$ in year 2010; while grassland had a similar situation from $29.30 \%$ in 2005 to $28.49 \%$ in 2010. The settlement/built up area occupied a considerable portion with a slight increase from $30.10 \%$ in 2005 to $30.79 \%$ in 2010 .

The open ground which included both mining grounds and bare surfaces covered just a handful area and it shows a slight increase from $0.56 \%$ in 2005 to $0.71 \%$ in 2010 . During the entire study period, there were slight overall changes in the land cover and land use characteristics. This slight change could be attributed to the short time interval from 2005 to 2010 , since just little changes would have taken place during the time. As a result, there was a gradual decrease of vegetation, both dense and non-forest. The loss contributed to slight gain in open ground and settlement/built up area. 
Table 7. Result of the area (in $\mathrm{km}^{2}$ ) covered by the various land use/land cover types

\begin{tabular}{ccccccccc}
\hline \multirow{2}{*}{$\begin{array}{c}\text { Year of image } \\
\text { acquisition }\end{array}$} & \multicolumn{2}{c}{ Dense forest } & \multicolumn{2}{c}{ Open ground } & \multicolumn{2}{c}{ Settlement/built up area } & \multicolumn{2}{c}{ Grassland/non-forest } \\
\cline { 2 - 9 } & $\mathrm{km}$ & $\%$ & $\mathrm{~km}$ & $\%$ & $\mathrm{~km}$ & $\%$ & $\mathrm{~km}$ & $\%$ \\
\hline 2005 & 1.556200 & 40.04 & 0.02170 & 0.56 & 1.143892 & 30.10 & 1.113460 & 29.30 \\
2010 & 1.520408 & 40.00 & 0.02711 & 0.71 & 1.170115 & 30.79 & 1.082679 & 28.49 \\
\hline
\end{tabular}

\section{CONCLUSIONS}

This research assesses the environmental impacts of gemstone mining in Ijero-Ekiti using conventional and remote sensing methods. Water test carried out on stream, well and pond show that the water is slightly acidic. Most of the $\mathrm{pH}$ values of the water samples were within the WHO and NIS permissible limits $(6.5-8.5)$. Only the $\mathrm{pH}$ of $W_{2}(6.32)$ and $W_{6}(6.15)$ fell out of the WHO and NIS acceptable limit. The result of the Total Dissolved Solid (TDS) obtained from the water analysis shows that the TDS ranges between 50 and $150 \mathrm{mg} / \mathrm{l}$ which was compared with the WHO and NIS acceptable limits (1000 and $500 \mathrm{mg} / \mathrm{l}$ respectively). The TDS value of the entire water sample including the control sample $W_{C}$ was low based on the above stated result. The result of the alkalinity test obtained shows that the alkalinity ranges between 56 and $272 \mathrm{mg} / \mathrm{l}$ in the water samples. The acceptable limit as given by WHO is $100 \mathrm{mg} / \mathrm{l}$ which shows that most of the water samples tested exceeds the permissible limit. The hardness of the water samples including the control sample ranges between 16.8 and $113.4 \mathrm{mg} / \mathrm{l}$. All were found to be within the permissible limit of 500 and $150 \mathrm{mg} / \mathrm{l}$ as given by WHO and NIS respectively. Even though most of the parameters tested for in the water were found to be within the acceptable limit as stated by WHO and NIS, iron (Fe) concentration was found to be exceptionally higher than the standard limit as prescribed by WHO and NIS standards as $0.3 \mathrm{mg} / \mathrm{l}$. The result of the Iron concentration in the water samples ranges between 0.39 and $12.50 \mathrm{ppm}$ rendering the water resources in the study area unfit for drinking. The water pollution may not be a direct effect of the gemstone mining in the area as the result of some of the test carried out on a control sample which is about $2 \mathrm{~km}$ away from the gemstone mine also shows the same property as the water samples near the mine.

Soil test carried out shows that the soil is slightly acidic in nature and has a very high organic matter content and nitrogen but low in organic carbon. The percentage nitrogen content of the samples ranges between 0.69 and 0.73 which is high in rating. The percentage soil organic matter ranges between 0.23 and 5.67 for both the excavated and undisturbed area. Samples $S_{2}$ and $S_{3}$ were within the range except for $S_{1}$ $(0.23 \%)$ and $S_{4}(1.34 \%)$ that were found to be low and the control sample $S_{C}$ having higher organic matter attributed to being at a farther distance from the disturbed/excavated area. The soil is good for farming due to its high nitrogen content and organic matter content which favours agriculture.

The result of the NDVI carried out on satellite images for four years between 1991 and 2013 shows that the mean for 1991 and 2013 were 0.2190 and 0.2435 respectively. It was observed that the mean vegetation index for 2013 is more than the mean vegetation index for
1991 before gemstone mining activity even commenced in the study area. This is an attestation to the fact that gemstone mining has not negatively impacted the vegetation of the study area. Though a decrease in the vegetative index from 1991 to 2010 was observed but a sharp increase was seen in the index in 2013. This may be attributed to reduction in the number of artisanal miners or investors coming into the area and improvement in farm practices and application of new farming method and fertilizers.

From the analysis carried out on high resolution satellite imageries of the year 2005 and 2010 to detect changes in land use over the years, it was observed that there is only a slight change in the land use and land cover characteristics. This could be attributed to a short time interval in the images used as there was slight decrease in vegetation, both dense and non-forest. Also it may be as a result of small scale mining works done in the area. The loss contributed to slight gain in open ground and built up area.

It can be deduce from all the tests and analyses carried out through this research that the negative impact of gemstone mining on the environment is minimal as the water test done has proved the water resources (well, pond and stream) as unfit for drinking purposes but it can be used for other purposed such as domestic and irrigation. Also, the soil test carried out has proved that the soil in the study area is good for agricultural purposes because it is high in nitrogen and organic matter content. This assertion can be back up by the result of the NDVI analysis which shows an increase in vegetation.

\section{RECOMMENDATIONS}

Based on the aforementioned results, the following recommendations are made to address the environmental and health problems created by the gemstone mining activities:

1. Farmers cultivating the land where samples $S_{1}$ and $S_{4}$ were gotten from should apply fertilizer or manure to the land to bring up the percentage organic matter of the soil.

2. Association in the area should collaborate to provide more borehole water facilities for the entire community.

3. The Federal Ministry of Mines and Steel Development should ensure that the gemstone mining company complies with environmental management policy to reduce the environmental effects of mining to the barest minimum.

4. The National Space Research and Development Agency (NASRDA) should be more effective and open in its provision of satellite imagery for research purpose. Also more work should be done by the agency in acquisition of high resolution satellite imagery for all locations within Nigeria. 


\section{ACKNOWLEDGEMENTS}

This research is sponsored by FUTA $003 / 15$ project. The authors appreciate their contribution toward the success of the work. Input of the National Space Research and Development Agency (NASRDA) is also appreciated.

\section{REFERENCES}

Ademoroti, C.M.A. (1996). Standard Methods for Water and Effluents Analysis. Ibadan: Foludex Press Ltd, (3), 29-118.

Afeni, T.B., \& Isiaka, A.F. (2009). Environmental Effects of Marble Exploitation and Processing at Igarra, Nigeria. International Journal of Engineering, 3(1), 45-56.

Ajakaye, D.E. (1985). Environmental Problems Associated with Mineral Exploitation in Nigeria. In 21st Annual Conference of the Nigeria Mining and Geosciences Society Held at Jos (pp. 140-148).

Garg, J.K., Narayan, A., \& Basu, A. (1988). Monitoring Environmental Changes Over Kudremukh Iron Ore Mining Area, India Using Remote Sensing Technique. In Proceedings of the Indo-British Workshop on Remote Sensing of Environment in Mining Field (pp. 41-47). Dhanbad: ISM.

Gregorio, D.A., \& Jansen, L.J. (1998). Land Cover Classification System (LCCS): Classification Concepts and User Manual. Rome: FAO.

Guidelines for Drinking Water Quality. (2011). Geneva: World Health Organization.

Harris, P.M., \& Ventura, S.J. (1995). The Integration of Geographic Data with Remotely Sensed Imagery to Improve Classification in an Urban Area. Photogrammetric Engineering and Remote Sensing, 61(8), 993-998.

Hendershot, W.H., Laldnde, H., \& Duquette, M. (1993). Soil Reaction and Exchangeable Acidity in Soil Sampling and Methods of Analysis. Canadian Society of Soil Science, 141-145.

Joshi, P.K., Kumar, M., Midha, N., Yanand, V., \& Wal, A.P. (2006). Assessing Areas Deforested by Coal Mining Activities through Satellite Remote Sensing Images and Gis in Parts of Korba, Chattisgarh. Journal of the Indian Society of Remote Sensing, 34(4), 415-421.

https://doi.org/10.1007/bf02990926
Nigerian Industrial Standard NIS 554-2007. (2014). Nigerian Standard for Drinking Water Quality. Abuja, Nigeria: SON Governing Council.

Nouri, H., Beecham, S., Anderson, S., \& Nagler, P. (2014). High Spatial Resolution WorldView-2 Imagery for Mapping NDVI and Its Relationship to Temporal Urban Landscape Evapotranspiration Factors. Remote Sensing, 6(1), 580-602. https://doi.org/10.3390/rs6010580

Olusiji, S.A. (2011). Stream Sediment Geochemical Survey of Ara, Epe and Ijero Area, South Western Nigeria. International Journal of Science and Technology, 1(6), 269-274.

Space Application Centre. (1990). Impact of Mining Activities and Superthermal Power Stations on Environment. Project Report No. RSAM/SAC/ENVN/PR/08/90. Bangalore: Indian Space Research Organization.

Schowengerdt, R.A. (2007). Remote Sensing: Models and Methods for Image Processing. New York: Elsevier.

Schulte, E.E. (1995). Recommended Soil Organic Matter Tests. Recommended Soil Testing Procedures for the North Eastern USA. Northeastern Regional Publication, (493), 52-60.

Shaban, A. (2010). Support of Space Techniques for Groundwater Exploration in Lebanon. Journal of Water Resource and Protection, 2(5), 469-477. https://doi.org/10.4236/jwarp.2010.25054

Sinha, R.K., Pandey, D K., \& Sinha, A.K. (2000). Mining and the Environment: A Case Study from Bijolia Quarrying Site in Rajasthan, India. The Environmentalist, 20(3), 195-203.

Tekalign, T., Haque, I., \& Aduayi, E.A. (1991). Soil, Plant, Water, Fertilizer, Animal Manure and Compost Analysis (in Plant Sciences Division Working Document, No. B13). Addis Ababa, Ethiopia: International Livestock Centre for Africa.

Wershaw, R.L., Fishman, M.J., Grabbe, R.R., \& Lowe, L.E. (1987). Methods for the Determination of Organic Substances in Water and Fluvial Sediments. Washington: Government Printing Office.

Fishman, M.J., \& Friedman, L.C. (1989). Methods for Determination of Inorganic Substances in Water and Fluvial Sediments. Reston, Virginia: Geological Survey.

\section{ВИЗНАЧЕННЯ ВПЛИВУ ВИДОБУТКУ ДОРОГОЩІННОГО КАМІННЯ НА НАВКОЛИШНС СЕРЕДОВИЩЕ В ІЖЕРО-ЕКІТІ, НІГЕРІЯ}

\section{Т.Б. Афені, Ф. Ібітолу}

Мета. Вивчити вплив на навколишне середовище і жителів Іжеро-Екіті (штат Екіті, Нігерія) розробки родовищ дорогоцінного каміння.

Методика. Для проведення досліджень проведено відбір проб грунтів і води з прилеглої місцевості шахти. Застосовано дистанційне зондування в якості інструменту екологічної оцінки для визначення нормалізованого відносного індексу рослинності (HBIP), а також карти землекористування й рослинного покриву за допомогою програмного забезпечення ArcGIS 10.

Результати. Встановлено, що взяті у діючій свердловині та ставку-відстійнику зразки води $є$ слабокислотними. Повний аналіз розчиненої твердої речовини й аналіз на жорсткість води показали менший розкид величин, ніж допустима межа, що визначена галузевим стандартом Нігерії та Всесвітньої організацій охорони здоров'я (ВООЗ), а рівень концентрації заліза значно вище допустимих меж, визначених ВООЗ для водних ресурсів, непридатних для пиття. Аналіз грунту в цьому районі підтвердив, що він придатний для сільського господарства, оскільки містить багато азоту й органічної речовини.

Наукова новизна. За результатами аналізу НОІР спостерігається зростання вегетативного індексу з 0.2190 у 1991 році до 0.2435 у 2013 році. Аналіз визначення змін у землекористуванні також показав незначне річне різноманіття протягом року з 2005 до 2010. Це пояснюється тим фактом, що видобуток дорогоцінного каміння ведеться в невеликих масштабах.

Практична значимість. Результати аналізів якості грунтів і води в районі видобутку можна використовувати при складанні рекомендацій для місцевого населення. Для підвищення продуктивності аграрного сектора в районі, де були взяті проби $S_{1}$ i $S_{4}$, слід застосовувати добриво, аби збільшити процентний вміст органічної речовини у грунті. Дистанційне зондування довело свою ефективність для оцінки погіршення екологічної 
ситуації. Це дає можливість створення бази даних регіональної оцінки стану навколишнього середовища, що досить важко досягається при використанні традиційної методики.

Ключові слова: навколишнє середовище, видобуток дорогоцінного каміння, вплив, дистанційне зондування, вегетативний індекс

\section{ОПРЕДЕЛЕНИЕ ВЛИЯНИЯ ДОБЫЧИ ДРАГОЦЕННЫХ КАМНЕЙ НА ОКРУЖАЮЩУЮ СРЕДУ В ИЖЕРО-ЭКИТИ, НИГЕРИЯ}

\section{Т.Б. Афени, Ф. Ибитолу}

Цель. Изучить воздействие на окружающую среду и жителей Ижеро-Экити (штат Экити, Нигерия) разработки месторождений драгоценных камней.

Методика. Для проведения исследований произведен отбор проб почв и воды из окрестностей шахты. Применено дистанционное зондирование в качестве инструмента экологической оценки для определения нормализованного относительного индекса растительности (НОИР), а также карты землепользования и растительного покрова посредством программного обеспечения ArcGIS 10.

Результаты. Установлено, что взятые в действующей скважине и пруде-отстойнике образцы воды являются слабокислотными. Полный анализ растворенного твердого вещества и анализ на жесткость воды показали меньший разброс величин, чем допустимый предел, определенный отраслевым стандартом Нигерии и Всемирной организаций здравоохранения (ВО3), а уровень концентрации железа значительно выше приемлемых пределов, определенных ВОЗ для водных ресурсов, непригодных для питья. Анализ почвы в этом районе подтвердил, что она пригодна для сельского хозяйства, поскольку содержит много азота и органического вещества.

Научная новизна. По результатам анализа НОИР наблюдается рост вегетативного индекса с 0.2190 в 1991 году до 0.2435 в 2013 году. Анализ определения изменений в землепользовании также показал незначительное годовое разнообразие на протяжении года с 2005 до 2010. Это объясняется тем фактом, что добыча драгоценных камней ведется в небольших масштабах.

Практическая значимость. Результаты анализов качества почв и воды в районе добычи можно использовать при составлении рекомендаций для местного населения. Для повышения продуктивности аграрного сектора в районе, где были взяты пробы $S_{1}$ и $S_{4}$, следует применять удобрение, чтобы увеличить процентное содержание органического вещества в почве. Дистанционное зондирование доказало свою эффективность для оценки ухудшения экологической ситуации. Это дает возможность создания базы данных региональной оценки состояния окружающей среды, что весьма затруднительно при использовании традиционной методики.

Ключевые слова: окружающая среда, добыча драгоценных камней, влияние, дистанционное зондирование, вегетативный индекс

\section{ARTICLE INFO}

Received: 22 October 2017

Accepted: 20 December 2017

Available online: 26 December 2017

\section{ABOUT AUTHORS}

Thomas Busuyi Afeni, Doctor of Philosophy, Senior Lecturer of the Department of Mining Engineering, Federal University of Technology Akure, Ilesha-Akure Expressway, P.M.B. 704, Akure, Ondo State, Nigeria. E-mail: tbafeni@futa.edu.ng

Femi Ibitolu, Master Engineering, Graduate Student of Earth Systems and Environmental Engineering, City College of New York, $160 \mathrm{nt}$ Avenue, Steiman Hall Room ST-129, 10031, New York, United States. E-mail: fembit123@gmail.com 